\title{
ADAT, BUDAYA DAN AGAMA LOKAL Studi Gerakan Ajeg Bali Agama Hindu Bali
}

\author{
Deni Miharja \\ UIN Sunan Gunung Djati Bandung \\ Denimiharja78@yahoo.com
}

\begin{abstract}
Abstrak
Tulisan ini memfokuskan kajiannya pada gerakan Ajeg pada agama Hindu di Bali. Pada satu sisi Ajeg Bali dipahami sebagai adat masyarakat Hindu Bali sebagai upaya untuk melestarikan nilai dan tradisi leluhurnya agar tidak hilang. Pada sisi lain, Ajeg Bali pun di pahami sebagai sebuah gerakan politik kebudayaan yang muncul ke permukaan sebagai respon orang-orang Bali yang beragama Hindu terhadap berbagai persoalan. Dalam perkembangannya, Ajeg Bali bahkan diyakini sebagai Agama Lokal yang tumbuh dan berkembang dalam tradisi masyarakat Bali.. Hasil kajian menunjukkan bahwa pemahaman tentang Gerakan Ajeg Bali terpecah menjadi dua bentuk, satu fihak berpaham terhadap artikulasi dan fihak lain berfaham pada disartikulasi. Meski berbeda, keduanya menginginkan nilai-nilai adat tetap terpelihara dan terjaga secara utuh dari pengaruh budaya asing ataupun budaya global. Singkatnya gerakan Ajeg Bali dapat dipandang sebagai latihan intelektual dalam menciptakan simbol-simbol kebudayaan baru secara terus menerus untuk mendefinisikan kembali identitas ke-bali-an orang Bali demi kepentingan kekuasaan.
\end{abstract}

\section{Abstract}

TRADITION, LOCAL CULTURE AND RELIGION: A study of the Ajeg Movement of Balinese Hinduism: This paper focuses on the study of Ajeg movement among the Balinese Hinduism. On the one hand the Ajeg movement is percieved as a tradition of Balinese Hindu community in an effort to preserve the values and traditions of their ancestors; On the other hand, the Ajeg Bali can also be seen as a cultural political movement that comes up to surface as a response of Balinese Hindu to various problems. 
During its development, Ajeg Bali even believed as a Local Religion that grows and evolves within the Balinese tradition. This study reveals that the Bali Ajeg Movement splits into two forms, one side concerns with articulation while another emphasis on disarticulation. Although the two tendencies are different, they equally desire to maintain traditional values and preserve its intact from the influences of foreign or global culture. In short, the Bali Ajeg movement can be seen as an intellectual exercise in creating new cultural symbols to redefine the Balinese identity for the sake of socio-political power.

Kata Kunci: adat, budaya, agama lokal, ajeg bali, artukulasi, disartukulasi, agama hindu

\section{A. Pendahuluan}

Berbicara budaya tentu akan selalu terkait dengan nilai dan norma suatu kebudayaan masyarakat, maka penting untuk diketahui bahwa nilai dan norma siapa yang sebenarnya kita bicarakan. Kita bisa saja terjebak pada pengasumsian bahwa yang dijadikan nilai dan norma kebudayaan adalah nilai dan norma yang dianut oleh kelompok dominan. Asumsi semacam ini bisa mengabaikan adanya perubahan-perubahan dalam dunia sekarang. Yaitu munculnya identitas budaya kecil-kecil yang sangat bervariatif dalam satu bangsa. ${ }^{1}$

Sebagaimana maksud tersebut, penulis mencoba mengkaji tentang adat, budaya, agama lokal dalam kasus Ajeg Bali yang terjadi dalam Agama Hindu di Bali. Secara sepintas bisa dikatakan bahwa Ajeg Bali adalah sebuah konsep adat yang sudah dibangun sejak lama yang kemudian membudaya dalam prilaku keagamaan masyarakat Hindu Bali sebagai upaya untuk tetap melestarikan nilai tradisi leluhurnya agar tidak hilang, bahkan dalam perkembangannya Ajeg Bali diyakini sebagai Agama Lokal yang tumbuh dan berkembang dalam tradisi masyarakat Bali.

Ajeg Bali pun di pahami sebagai sebuah gerakan politik kebudayaan yang muncul ke permukaan sebagai respon orang-orang Bali yang beragama Hindu terhadap berbagai persoalan ${ }^{2}$. Akan tetapi

${ }^{1}$ Esther Kuntjara, Penelitian Kebudayaan Sebuah Panduan Praktis, (Jakarta; Graha Ilmu, 2006), h. 17.

${ }^{2}$ Misalnya respon terhadapa persoalan ledakan bom di Legian pada bulan oktober 2002, yang menimbulkan banyak korban jiwa. 
setelah dipelajari secara seksama, akhirnya ditemukan bukti sejarah bahwa semangat mengajegkan $n^{3}$ Bali sudah ada sepanjang sejarah Bali, dengan nama dan perwujudan yang berbeda-beda. Semangat itu selalu dibangkitkan kembali oleh para intelektual organik ${ }^{4}$ dari berbagai golongan dengan cara memanfaatkan atau mengelola sedemikian rupa wacana-wacana yang dianggap dapat mengikis identitas kebalian ${ }^{5}$. Demi menjaga identitas kebalian itu, ${ }^{6}$ mereka berlomba mengartikulasikan Bali sebagai konsep kebudayaan, namun memaknainya secara berbeda.

Semua orang akan sepakat, bahwa Bali adalah sebagai tempatnya masyarakat yang mayoritas memeluk agama Hindu, karena memang secara historis, kultur yang dibangun di Bali lebih dominan ada dalam pengaruh Agama Hindu. Sehingga ketika berbicara Bali, maka akan selalu identik dengan Agama Hindu, bahkan kemudian Bali dikenal sebagai Hindu Darma, artinya prilaku keberagamaan lebih dominan ada dalam tradisi

${ }^{3}$ Mengajegkan adalah kata bentukan dari ajeg. Dalam bahasa Bali, ajeg berpadanan jejeg, tuara obah, tuara seng, artinya tegak, tetap, teratur, tidak berubah. Lihat I Wayan Simpen AB, Kamus Bahasa Bali (Denpasar: PT Mabhakti,1985), h. 9. Dalam, I Nyoman Wijaya, Mencintai Diri Sendiri:Gerakan Ajeg Bali dalam sejarah Kebudayaan Bali 1910-2007. Disertasi , h. 1

${ }^{4}$ Istilah intelektual organik digunakan untuk membedakannya dengan pengertian intelektual secara umum. Konsep intelektual organik yang digunakan dalam studi ini mengacu pada Gramsci yang membagi intelektual menjadi dua kelompok, yakni tradisional dan organik. Intelektual organik adalah intelektual yang kehadirannya terkait dengan struktur produktif dan politik masyarakat, yakni dengan kelompok atau atau kelas yang mereka wakili. Mereka tampil sebagai "fungsionaris" atau “deputi” kelompok penguasa, yang aktivitas intelektualnya diarahkan untuk memproduksi dan menyebarkan filsafat, teori politik maupun ekonomi, dan sebagainya. Sementara, intelektual tradisional adalah semua orang yang menunjukkan aktivitas keintelektualan. Lihat, Antonio Gramsci, Slection From The Prison Notebooks, edited and translated by Quintin Hoare and Geoffrey Nowell Smith (New York: International Publisher, 1971), h. 5,9, dan 12.

${ }^{5}$ Artikulasi diterjemahkan sebagai ngadungang (bahasa Bali, yang artinya menyepadankan, menyesuaikan atau menyelaraskan dua hal yang berbeda, terjemahan dari I Nyoman Wijaya) yang bermakna mengungkapkan dan menghubungkan bersama-sama. Lihat, Mark Hobart,"The end of the world news:television and a problem of articulation in Bali," dalam International Journal of Cultural Studies, Volume 3, 1,79-102, June, 1999, h. 19, footnote 24.

${ }^{6}$ I Nyoman Wijaya, dalam Prakata Disertasi Mencintai Diri Sendiri: Gerakan Ajeg Bali dalam sejarah Kebudayaan Bali 1910-2007. 
kehinduan. Dominasi serta hegemoni Hindu Bali pun kemudian menjadi wajar dalam perkembangan kemasyarakatan, hal ini terbukti dengan adanya konsep Ajeg Bali, yang menurut hemat penulis adalah sebagai bentuk dominasi dan hegemoni terhadap budaya lain yang dianggap akan mengganggu atau merusak kultur Hindu Bali.

\section{B. Memahami Konsep Umum tentang Adat, Budaya dan agama Lokal}

Pemahaman sederhana tentang adat, bisa dimaknai sebagai sebuah kebiasaan yang berlangsung cukup lama dan mengalami proses dialektik dalam kehidupan masyarakat yang dipegang teguh, sehingga menjadi sebuah prilaku kolektif yang mesti ditaati dan dilaksanakan secara bersama. Dengan demikian, adat muncul berkaitan dengan hadirnya etnis atau suku bangsa yang selanjutnya akan menjadi identitas bagi suatu etnis atau suku bangsa tertentu.

Ketika adat sudah menjadi identitas etnis tertentu, maka ia akan menjadi sebuah tradisi yang melembaga. Di mana tradisi adalah kebiasaan sosial yang diturunkan dari satu generasi ke generasi lainnya melalui proses sosialisasi. Tradisi menentukan nilai-nilai dan moral masyarakat, karena tradisi merupakan aturan-aturan tentang hal apa yang benar dan hal apa yang salah menurut warga masyarakat. Konsep tradisi itu meliputi pandangan dunia (worldviews) yang menyangkut kepercayaan tentang masalah kehidupan dan kematian serta peristiwa alam dan makhluknya, atau konsep tradisi itu berkaitan dengan sistem kepercayaan, nilai-nilai dan cara serta pola berpikir masyarakat. ${ }^{7}$

Robert Redfiled, mempopulerkan istilah tradisi besar dan tradisi kecil, atau tradisi feodal dan tradisi rakyat. Konsep tradisi besar atau bangsawan itu dikaitkan dengan cara hidup warga masyarakat kalangan atas (istana) dari suatu peradaban, cara hidup itu diwarisi dan diturunkan dari satu generasi ke generasi lainnya. Sedangkan konsep tradisi rakyat digunakan sebagai konsep yang berlawanan dengan tradisi bangsawan atau tradisi besar, yang menjelaskan tentang kebudayaan rakyat biasa dalam suatu

7Judistira K. Garna, Пlтu-Пmu Sosial Dasar - Konsep - Posisi, (Bandung: Pascasarjana Unpad, 2001), h. 186. 
kebudayaan tertentu, tradisi rakyat itu seringkali menyerap tradisi besar setelah mengalami proses penyesuaian. ${ }^{8}$

Adapun konsep awal tentang kebudayaan berasal dari E.B. Tylor yang mengemukakan bahwa culture atau civilization itu adalah complex whole includes knowledge, belief, art, morals, law, custom, and any other capabilities and habits acquired by man as a member of society. Batasan tentang kebudayaan ini mengemukakan aspek kebendaan dan bukan kebendaan itu sendiri atau materi dan nonmateri, sebagaimana Tylor kemukakan bahwa kebudayaan ialah keseluruhan kompleks yang meliputi pengetahuan, kepercayaan, kesenian, moral, hukum dan kemampuan-kemampuan lainnya serta kebiasaan yang diperoleh manusia sebagai anggota masyarakat. ${ }^{9}$

Kebudayaan adalah alat konseptual untuk melakukan penafsiran dan analisis ${ }^{10}$. Jadi keberadaan kebudayaan sangatlah penting, karena akan menunjang terhadap pembahasan mengenai eksistensi suatu masyarakat. Kebudayaan sebagai suatu sistem budaya, aktivitas dan hasil karya fisik manusia yang berada dalam suatu masyarakat dimana kemunculannya itu diperoleh melalui proses belajar, baik itu formal maupun informal. Hal ini menunjukan bahwa kebudayaan tidak akan hadir dengan sendirinya, melainkan ada karena adanya manusia dalam komunitas sosial, sehingga antara manusia, masyarakat dan kebudayaan akan saling mendukung. Manusia menciptakan kebudayaan sebagai usaha untuk mempertahankan hidupnya di muka bumi ini, karena dengan kebudayaan manusia akan mampu melaksanakan tugasnya di muka bumi ini sebagai khalifah. Dengan kebudayaan pula kehidupan keagamaan manusia akan nampak, dan ini menjadikan pembeda terhadap jenis makhluk lainnya yang ada di muka bumi ini.

Selanjutnya, Ralph Linton, mengajukan batasan kebudayaan yang lebih spesifik, menurutnya bahwa kebudayaan adalah" a culture is the configurationas of learned behavior and results of behavior whose components elements are shared and trasmistted by the members of a particular society. Pernyataannya ini mengandung makna bahwasannya kebudayaan atau budaya dianggap sebagai milik khas

\footnotetext{
${ }^{8}$ Ibid.

${ }^{9}$ Ibid., h. 157.

${ }^{10}$ Ibid.
} 
dari manusia, walaupun berbagai studi yang dilakukan kemudian tentang non human primate.

Sedangkan A.L. Kroeber mengganggap bahwa kebudayaan itu memiliki sifat yang superorganik yaitu keberadaannya telah mengatasi keberadaan dari setiap individu atau organic yang artinya walaupun kebudayaan itu dilakukan oleh semua orang, tetapi wujud atau keberadaannya bebas dari individu tertentu. Manusia sebagai homo sapiens, di dalam hidupnya akan senantiasa berkreasi tentang eksistensinya di dunia. Manusia akan memahami lingkungannya yang pada akhirnya manusia akan menghasilkan kebudayaan. Kebudayaan dapat dipelajari dan diciptakan oleh manusia karena pada diri manusia itu memiliki, pertama, kemampuan untuk berbicara (bahasa), kemampuan ini sangat menentukan terhadap perjalanan manusia di muka bumi, dengan bahasa manusia dapat merumuskan berbagai hal yang ada dalam pikirannya, sehingga kemungkinan kebudayaan pun muncul dari kemampuan manusia di dalam berbicara. Manusia, tentunya memiliki bentuk perwujudan yang lebih halus dalam mengemukakan bahasanya, manusia mampu membuat bahsa secara lisan ataupun tertulis dan melalui inilah manusia dapat menciptakan karyanya bagi kelangsungan hidupnya.

Kedua, manusia memiliki akal atau otak besar. Inilah yang membedakan antara manusia dengan makhluk lainnya, dimana otak manusia yang besar ini telah mampu berpikir secara lebih luas dan mendalam yang berbeda dengan makhluk lainnya. Dengan otaknya, manusia berpikir untuk menciptakan suatu budaya yang akan menunjang terhadap kehidupannya di muka bumi ini.

Dengan kemampuan bahasa dan akal juga, maka manusia dapat belajar dan menciptakan kebudayaan, bahkan manusia dapat menciptakan kebudayaan-kebudayaan baru yang diperlukan. Dengan belajar terhadap budaya, berarti manusia telah menunjukan dirinya sebagai manusia yang memiliki kebudayaan/ manusia yang berperadaban. Manusia dengan budaya merupakan dua komponen yang saling menunjang, karena dengan budaya manusia mampu mempertahankan hidupnya, begitu juga budaya dengan manusia telah mengalami berbagai perkembangan. Dengan demikian, yang paling penting bahwa kebudayaan yang diciptakan oleh manusia 
akan terus menerus berlangsung dan mengalami perkembangan dari satu generasi ke generasi berikutnya dimana telah terjalinnya suatu komunikasi yang baik, sehingga kebudayaan terdahulu tetap akan ada dan terpelihara. Ini terjadi karena kebudayaan itu diperoleh manusia secara komulatif dari generasi ke generasi.

Sifat manusia yang paling umum adalah adanya keinginan untuk menciptakan dan mengembangkan. Dengan demikian, manusia akan senantiasa menciptakan kebudayaan yang baru yang diraskan akan membantudan mendukung terhadapkeberlangsungan hidupnya di muka bumi ini. Kemudian setelah menciptakan , maka manusia berusaha untuk mengembangkannya dengan model yang bermacam-macam tergantung dari selera yang diinginkan.

Manusia di dalam proses menciptakan dan mengembangkan kebudayaan, tergantung kepada kondisi social behavior di mana mereka tinggal. Hal ini menunjukan bahwa antara manusia yang tinggal di satu daerah dengan manusia yang tinggal di daerah lain, maka akan terlihat adanya perbedaan di dalam cara menciptakan dan mengembangkan suatu budaya dan ini tentunya merupakan suatu bentuk keragaman corak berpikir yang dimiliki oleh manusia.

Di dalam hidupnya manusia selalu berhubungan dengan lingkungannya, sehingga dengan saling berhubungan tersebut, maka manusia akan memperoleh budaya. Budaya sebagai hasil proses adaptasi manusia terhadap perubahan-perubahan alam fisik/ lingkungan manusia itu sendiri telah mendorong manusia untuk lebih kreatif didalam memahami akan keberadaan lingkungan sekitarnya, kebudayaan yang diciptakan oleh manusia akan beragam, hal ini tergantung dari selera manusia itu sendiri didalam memahami akan kebutuhan hidupnya. Budaya yang dikembangkan oleh manusia akan selalu dinamis dan terus menurus mengalami suatu perbaikan dari yang paling awal disesuaikan dengan tingkat kebutuhan dari manusia itu sendiri di dalam menjalani kehidupannya.

Ada dua hal yang mempengaruhi manusia di dalam memperoleh budayanya. Pertama, berkaitan dengan lingkungan adaptasi biologis. Maksudnya adalah adanya penyesuaian terhadap keinginan-keinginan alamiah manusia yang muncul dari dalam dirinya sendiri, dimana manusia akan terus berusaha secara 
maksimal di dalam pemenuhan terhadap kebutuhan hidupnya. Kedua, adaptasi cultural, maksudnya usaha manusia di dalam mempertahankan hidupnya diperoleh dengan cara menyesuaikan diri dengan kondisi budaya yang ada pada suatu masyarakat, sehingga kemunculan budaya pada manusia akan beragam.

Kebudayaan adalah satu cara hidup yang dikembangkan oleh sebuah masyarakat guna memenuhi keperluan dasarnya untuk dapat bertahan hidup, meneruskan keturunan dan mengatur pengalaman sosialnya. Hal-hal tersebut adalah seperti pengumpulan bahanbahan kebendaan, pola organisasi social, cara tingkah laku yang dipelajari, ilmu pengetahuan, kepercayaan dan kegiatan lain yang berkembang dalam pergaulan manusia. Oleh sebab itu, kebudayaan adalah sumbangan manusia kepada alam lingkungannya. ${ }^{11}$

Kebudayaan setiap masyarakat atau suku bangsa terdiri atas unsur-unsur besar maupun unsur-unsur kecil yang merupakan bagian dari suatu kebulatan yang bersifat sebagai kesatuan. Ada beberapa unsur yang terdapat dalam kebudayaan, di mana kita sebut sebagai cultural universals, yang meliputi: ${ }^{12}$ Peralatan dan perlengkapan hidup manusia, Mata pencaharian hidup dan sistemsistem ekonomi, sistem kemasyarakatan, Bahasa (lisan dan tulisan), kesenian, sistem pengetahuan, dan Religi (sistem kepercayaan).

Selanjutnya, ketika memahami unsur-unsur kebudayaan tersebut, maka kita bisa mengetahui tentang terdapatnya unsurunsur kebudayaan yang mudah berubah dan ada pula unsur-unsur kebudayaan yang susah berubah. Adapun unsur-unsur budaya yang mudah berubah meliputi; seni, bahasa, teknologi. Sedangkan unsur-unsur budaya yang sulit berubah meliputi: agama (sistem kepercayaan), sistem sosial, dan sistem pengetahuan. ${ }^{13}$

Budaya juga dibedakan menjadi dua, yaitu budaya kecil (little culture), dan budaya besar (great culture). Budaya kecil adalah budaya yang berada pada suatu masyarakat yang lingkupnya kecil (dianut

${ }^{11}$ Josep S. Roucek \& Roland L. Warren, Pengantar Sosiologi, (Surabaya: PT. Bina Aksara, 1984), h. 10.

12 Lihat dalam bukunya Soerjono Soekanto, Sosiologi Suatu Pengantar, (Jakarta, Raja Grafindo Persada, 1990), h. 193.

${ }^{13}$ Dadang Kahmad, disampaikan pada waktu kuliah Antropologi, Pascasarjana IAIN Sunan Gunung Djati Bandung 2002. 
oleh beberapa orang saja) atau juga disebut local culture. Sedangkan budaya besar adalah budaya yang dianut oleh banyak orang dengan skala kepenganutannya luas. Ketika budaya kecil dan budaya besar saling berhubungan melalui proses asimilasi, maka kemungkinannya budaya kecil tersebut akan tersisihkan atau terkalahkan oleh budaya besar. Hal ini menunjuikan bahwa eksistensi dari budaya besar tersebut begitu kuat dan luas sehingga dengan mudah dan cepat bisa masuk kepada budaya kecil yang dianut oleh hanya bebera orang saja, misalkan.

Budaya kecil (budaya lokal) yang ada pada suatu masyarakat merupakan budaya yang sudah dibangun sejak adanya umat manusia di muka bumi ini atau dengan kata lain, keberadaan budaya kecil sebagai bentuk dari keberhasilan umat manusia di dalam mempertahankan hidupnya, karena bagaimanapun juga budaya kecil itu ada secara turun temurun dari satu generasi ke generasi selanjutnya. Kehadiran budaya besar, tentunya akan membawa suatu perubahan yang akan terjadi pada suatu komunitas yang memiliki budaya kecil, sehingga keberadaan budaya besar akan tetap eksis dan dan bisa jadi keberadaan budaya kecil akan mengalami penyusutan atau bahkan hilang dari eksistensinya pada suatu masyarakat. Bila digambarkan pola hubungan budaya kecil dengan budaya besar dalam pola asimilasi akan Nampak sebagai berikut: ${ }^{14}$

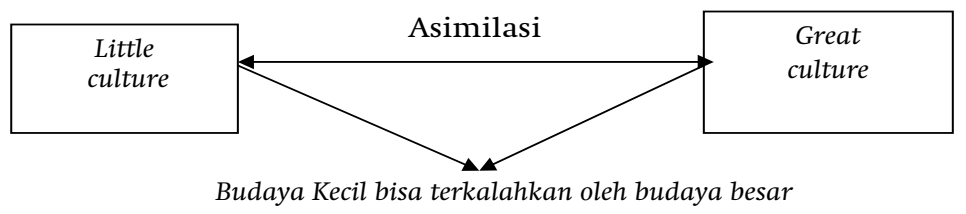

Selanjutnya, berbicara tentang agama lokal, maka harus dimulai dari pendefinisian dari agama itu sendiri, tentunya definisi agama sangat banyak dan tidak didapatkan satu kesimpulan yang disepakati oleh semua pihak. Penulis, dalam hal berangkat dari pemahaman agama secara pendekatan antropologi, di mana agama adalah produk budaya atau agama termasuk kebudayaan. Menurut

${ }^{14}$ Ibid. 
Jane Monning Atkinson ${ }^{15}$ sebagaimana ia mengutip Clifford Geertz tentang definisi agama melalui pendekatan Ilmu Antropologi,bahwa agama adalah sebagai sistem bentuk-bentuk simbolik ${ }^{16}$ yang mengungkapkan secara mendalam hakekat dasar bagi manusia, dan berfungsi sebagai pengantar tingkah laku manusia dalam menghadapi dunianya.

Berbicara tentang agama lokal, tentu bayangan awal adalah agama yang tidak termasuk pada kategori agama formal atau agama resmi yang diakui oleh Negara. Dengan demikian agama lokal adalah agama yang dianut dan berkembang pada masyarakat tertentu yang sistem kepercayaannya tidak sama dengan agama formal atau agama resmi, dengan kata lain agama lokal adalah agama asli yang dianut oleh suku bangsa tertentu, semisal suku Wana. Bahkan lebih lanjut disebutkan bahwa agama lokal termasuk agama tradisional dan agama formal dikatakan sebagai agama modern. Pendapat lain yang patut diperhatikan adalah pendapat E.E. Evans Pritchard ${ }^{17}$, yang menyebutnya agama primitive. Tentu pengklasifikasian ini berdasar atas kriteria yang ditemukan dalam kehidupan masyarakat.

Ada beberapa kriteria umum digunakan di Indonesia untuk membedakan agama dan bukan agama, di mana bagi ahli antropologi, pembedaan tersebut lebih tepat kalau dikatakan pembedaan antara agama modern dengan agama tradisional. Salah satu kriteria yang dimaksudkan adalah Monotheisme,

${ }^{15}$ Jane Monning Atkison adalah peneliti dan penulis tentang Agama dan Suku Wana di Sulawesi Tengah.

${ }^{16}$ Jane Monning Atkison,"Agama dan Suku Wana di Sulawesi Tengah", dalam Michael R.Dove (Penyunting), Peranan Kebudayaan Tradisional Indonesia Dalam Modernisasi, (Jakarta: Yayasan Obor Indonesia, 1985), h. 12.

17 E.E. Evans Pritchard adalah guru besar antropologi social pada Universitas Oxford (1946-1970), yang dimaksud agama primitive, menurutnya adalah merupakan bagian dari agama pada umumnya (species dari genus), dan bahwa semua orang yang berminat terhadap agama haruslah mengakui bahwa suatu studi tentang pandangan dan praktek -praktek keagamaan pada masyarakat primitive yang beraneka ragam coraknya, akan menolong kita untuk sampai pada kesimpulan-kesimpulan tertentu tentang hakikat agama pada umumnya, dan karenanya juga tentang apa yang dinamakan agama-agama yang lebih tinggi tingkatannya, atau agama-agama positif yang punya sejarah, atau agama-agama wahyu, termasuk agama-agama kita. 
kepercayaan kepada Tuhan Yang Maha Esa. Kedua, adanya Kitab Suci. Kedatangan Agama Modern ke Indonesia, ditandai dengan berkembangnya kebudayaan menulis, sehingga mereka membawa Kitab Sucinya, sedangkan agama tradisional secara umum, berkembang dalam masyarakat buta huruf, dengan demikian dapat dikemukakan argumentasi bahwa ada tidaknya kitab Suci tidak mencerminkan benar tidaknya suatu ajaran agama, melainkan sekedar tanda tingkat kemajuan teknologi dari masyarakat. ${ }^{18}$

Kriteria ketiga adalah pelintasan batas-batas etnis. Agama modern mempersatukan anggota berbagai kebudayaan dalam suatu kepercayaan tunggal, sedangkan agama tradisional seringkali memperkokoh persatuan suatu kebudayaan tertentu. Kriteria keempat adalah diukur dengan tingkat kemajuan. Kadang-kadang, perbedaan agama dan bukan agama di Indonesia bukan berdasarkan pertimbangan yang terdapat dalam kepercayaan itu sendiri, melainkan penilaian perkembangan sosial para pemeluknya. Mereka yang digolongkan "belum beragama" dianggap"terbelakang”, masih bodoh, dan tidak dapat diintegrasikan ke dalam kehidupan nasional. Agama merupakan lambang manusia berpendidikan, progresif dan berjiwa nasional. Menurut pandangan ini, klasifikasi belum agama bukan menunjukkan nilai spiritual, melainkan suatu komentar tentang tingkat kemajuan sosial dan ekonominya. ${ }^{19}$

\section{Gerakan Ajeg Bali dalam Agama Hindu}

Sebagai sebuah peristiwa budaya, semangat Ajeg Bali sudah semestinya dipahami dengan menggunakan konsep budaya. Fabian berpendapat budaya adalah konsep untuk objek studi. Ketika berfungsi sebagai konsep pemandu antropologi, budaya selalu menjadi ide post factum (setelah peristiwa), suatu gagasan yang diorientasikan pada masa lalu (pada kebiasaan dan tradisi), bersifat deskriptif tentang keadaan banyak hal (dan sering kali keadaan status quo), suatu ide nostalgic pada kondisi yang terbaik (ketika mencampurkan penelitian masyarakat eksotik dengan penyesalan) dan ideologeme reaksioner pada kondisi terburuk

${ }^{18}$ Ibid., h. 15-16.

${ }^{19}$ Ibid 
(ketika digunakan secara optimis untuk menjelaskan suatu cara sebagai variasi yang merupakan hasil diskriminasi dan kekerasan dalam banyak kasus). ${ }^{20}$

Semangat mengajegkan Bali muncul kembali pada akhir tahun 1990-an, pada pertengahan 2002, semangat itu berubah menjadi konsep Ajeg Bali. Tahun 2003, beberapa bulan setelah terjadinya ledakan bom Legian Oktober 2002, konsep Ajeg Bali berubah menjadi gerakan Ajeg Bali. Pada mulanya pihak-pihak yang menggagas dan membangkitkan kembali semangat Ajeg Bali, mengartikulasikan Bali sebagai konsep kebudayaan, yang dimaknai sebagai adat dan agama leluhur. Semua pihak sepakat dengan pemaknaan itu, Akan tetapi begitu semangat mengajegkan Bali berkembang menjadi gerkan Ajeg Bali, tanpa melepaskan artikulasi itu, substansinya melebar ke berbagai bidang kegiatan, termasuk aksi-aksi perlawanan terhadap keindonesiaan dan Islam. ${ }^{21}$

\section{Latar Belakang Munculnya Gerakan Ajeg Bali}

Setelah membaca dan mendalami secara seksama terkait latar belakang munculnya gerakan Ajeg Bali ini, penulis berkesimpulan bahwa yang melatarbelakangi munculnya Ajeg Bali ini, diantaranya:

Pertama, bahwa semangat mengajegkan Bali muncul setelah pemberlakuan Undang-undang Otonomi Daerah tahun 1999. Arah semangat ini mengerucut pada artikulasi Bali sebagai konsep kebudayaan yang dimaknai sempit, bahwa Bali memiliki bahasa daerah yakni bahasa Bali, memiliki adat yakni adat Bali, memiliki agama yakni agama Hindu, memiliki keseniaan yakni seni tradisional Bali, dan berpenduduk yakni orang-orang Bali yang beragama Hindu. Semua komponen itu harus diajegkan serta dilindungi dari upayaupaya penghancuran yang dilakukan oleh pihak dalam maupun luar Bali. ${ }^{22}$

${ }^{20} \mathrm{~J}$. Fabian,"Culture,Time and the object of Anthropology," dalam Time and The Work of Antrhropology (New York: Haewood, 1991), h. 193. Sebagaimana dikutip oleh I Nyoman Wijaya, Mencintai Diri Sendiri: Gerakan Ajeg Bali dalam Sejarah Kebudayaan Bali 1910-2007, Disertasi, UGM, 2009, h. 32.

${ }^{21}$ Ibid., h. 46.

${ }^{22}$ Ibid., h. 1 
Wacana di atas bermakna bahwa biarpun secara geopolitik Bali sudah menjadi bagian dari wilayah kekuasaan luar, Negara Republik Indonesia, namun secara geobudaya orang-orang Bali menganggap Bali adalah Bali, bukan daerah lain. Menurut Michel Picard munculnya semangat ini berkaitan erat dengan identitas kolektif orang-orang Bali yang berdasarkan pada kesadaran sifat umum bersama dan melekat pada symbol-symbol penyatuan. Mereka mendefinisikan dirinya berbeda dari orang-orang asing dan orang-orang dari wilayah Indonesia lainnya. Sebagai bangsa ${ }^{23}$ khusus, orang-orang Bali menganggap dirinya sebagai kelompok minoritas religius, benteng agama Hindu yang terancam oleh ekspansi agresif agama Islam dan Nasrani, dan sebagai suku khusus yang dicirikan dengan adat-istiadat mereka. ${ }^{24}$ Sama dengan Michel Picard, Tomas Reuter juga berpendapat orang-orang Bali menafsirkan identitasnya yang disebut kebalian, yang didasarkan secara simultan pada agama dan adat. ${ }^{25}$

Kedua, munculnya politik identitas. Menurut Henk Schulte berpendapat politik identitas itu merupakan hasil pengalaman historis dan serapan dari kebijakan pemerintah kolonial Belanda dari tahun 1846-1942, yang senantiasa berusaha membedakan Bali dengan daerah-daerah lain di wilayah Hindia Belanda, terutama Jawa. Hal ini dilakukan dengan cara memperkuat kontrol pemerintah atas rakyat, menangkis pengaruh-pengaruh Islam, Nasionalisme, dan membendung aktivitas missie zending. Tujuan itu dicapai melalui langkah-langkah strategis, yakni tidak akan memperdalam dan memperlebar selat Bali dan tidak akan pernah membangun jembatan penyeberangan Jawa-Bali. ${ }^{26}$ Kebijakan ini juga bukan merupakan hal baru, sebab sebelum zaman kolonial, raja-raja Bali sudah berusaha

\footnotetext{
${ }^{23}$ Konsep bangsa yang dimaksud bukan merupakan padanaan nation, melainkan kaum atau suku dalam bahasa Melayau. Ibid., h. 2.

${ }^{24}$ Sebagai bangsa Bali, yang sifatnya sangat khusus, orang-orang Bali memperkenalkan dirinya sebagai anggota suatu desa, kelompok keluarga, atau jaringan pura, bukan sebagai anggota orang Bali, Hasil diskusi dengan Michel Picard melalui emai, 17 Mei 2007, Ibid.

${ }^{25}$ Hasil diskusi dengan Michel Picard melalui email, 17 Mei 2007. Lihat juga Thomas Reuter, Global trends in religion and reaffirmation of Hindu identity in Bali," (Monash: University Press, 2008), h. 8.

${ }^{26}$ Henk Schulte Nordholt, Kriminalitas, Modernitas, dan Identitas dalam Sejarah Indonesia. (Yogyakarta: Pustaka Pelajar, 2002), h. 147-148.
} 
meredam meluasnya pengaruh luar di Bali, yang antara lain dilakukan dengan cara melokalisir pemukiman orang-orang Islam Jawa, Bugis, Lombok, Arab, dan Cina, dengan menempatkan mereka jauh dari pemukiman penduduk lokal. ${ }^{27}$

Ketiga, terjadinya persaingan antara golongan triwangsa dan golongan sudrawangsa. Menurut Henk Schulte Nordholt, kegagalan kerajaan Mengwi ${ }^{28}$ membangun kembali Majapahit, menjadi titik tolak dari semakin ketatnya pemisahan antara golongan triwangsa dan golongan sudrawangsa di Bali. Triwangsa adalah orang-orang yang memiliki hubungan pribadi dengan raja-raja Majapahit, baik secara politis maupun genealogis, sedangkan sudrawangsa, yang kemudian menyebut diri sebagai jabawangsa adalah orang kebanyakan. Golongan sudrawangsa ditempatkan pada lapisan yang terendah, dengan hal-hal politik, sosial, dan bahkan kultural yang sangat terbatas dibandingkan dengan yang diperoleh golongan triwangsa. Perbedaan hak ini sering melahirkan perselisihan antara golongan sudrawangsa dan triwangsa. ${ }^{29}$

Perselisihan antara golongan sudrawangsa dengan triwangsa sebagai konflik kasta. ${ }^{30}$ Konflik kasta ini sudah ada sejak zaman dulu. Wertheim dan I Gusti Ngurah Bagus. misalnya berpendapat, bahwa konflik kasta dapat dilacak sampai sebelum masa pemerintahan kolonial Belanda, namun tersembunyi di dalam dongeng, mite, dan karya-karya mistis lainnya. Konflik dalam wujud yang betul-betul nyata berlangsung tahun 1910, terjadi di Karangasem dan pada tahun 1911 di desa Beng, Gianyar. V.E. Korn berpendapat peristiwa

${ }^{27}$ Lihat antara lain, Adrian Vickers,"Hinduism and Islam in Indonesia: Bali and The Pasisir World,"Indonesia, no 44 (oktober), 1987; Anak Agung Gde Putra Agung, Peralihan Sistem Birokrasi dari Tradisional ke Kolonial (Yogyakarta: Pustaka Pelajar, 2001), h. 3.

${ }^{28}$ Kerajaan Mengwi adalah kerajaan yang ada di Bali yang pernah berkuasa pada tahun 1714 dan anaknya tahun 1729-1730 yang pernah melakukan ekspedisi politik ke Jawa Timur untuk membangun kembali kerajaan Majapahit. Lihat juga I Nyoman Wijaya, Mencintai Diri..., h. 5.

${ }^{29}$ Lihat, Henk Schulte Nordholt (1996), op.cit., h. 40, dalam I Nyoman Wijaya, h. 6

${ }^{30}$ Lihat antara lain, I Gusti Ngurah Bagus,"Pertentangan Kasta dalam bentuk Baru pada Masyarakat Bali," (Denpasar: Jurusan Antropologi, 1969) dan I Gusti Ngurah Bagus,"Surya Kanta Modern Kawangsan Movement of The Jaba Caste in Bali," Masyarakat Indonesia, Vol. II. No.2 (Jakarta: LIPI, 1975), dalam Ibid. 
itu adalah bentuk suatu penolakan golongan sudrawangsa terhadap penerapan peraturan kerja rodi yang didasarkan pada sistem kasta Belanda. Sistem kasta ala kolonial Belanda oleh Korn dinilai kurang fleksibel dibandingkan dengan yang di zaman kerajaan. ${ }^{31}$

Setelah kedua peristiwa perlawanan di atas berlalu, relasi antara golongan triwangsa dan sudrawangsa berubah-ubah. Pada suatu kesempatan mereka terlihat harmonis, namun pada kesempatan lain berseberangan. Menyangkut keajegan agama Bali, Henk Schulte Nordholt berpendapat, kedua kelompok intelektual dalam organisasi itu, yang dalam studi ini disebut sebagai intelektual organik saling isi mengisi dalam menyumbangkan strategi dan (kebangkitan kembali) kebudayaan Bali. ${ }^{32}$ Geoffrey Robinson berpendapat, bersama-sama pula mereka mengajegkan Bali terutama setelah mengetahui pemerintah kolonial Belanda ingin menjadikan Bali sebagai daerah Nasrani, terutama Katolik, yang dinilai akan dapat menghancurkan adat dan agama Bali. ${ }^{33}$

I Gusti Ngurah Bagus berpendapat golongan intelektual organic triwangsa terutama yang dari golongan Brahmana mengajegkan adat dan agama versi leluhurnya, yang sudah disesuaikan dengan kepentingan industri pariwisata, dengan cara memanfaatkan majelis tertinggi umat Hindu, Parisada Hindu Dharma Indonesia (PHDI). Golongan jabawangsa relatif tidak mampu melawan hegemoni kekuasaan golongan Brahmana ini. Perlawanan baru dapat dilakukan setelah munculnya Era Reformasi, tahun 1998. Pada tahun 2001 mereka berhasil mencapai tujuannya, yang antara lain terlihat dari terpilihnya seorang jabawangsa sebagai Ketua Umum Parisada Hindu Dharma Indonesia (PHDI). ${ }^{34}$

Selanjutnya, masih menurut I Gusti Ngurah Bagus, persaingan antara golongan triwangsa dan sudrawangsa (jabawangsa) terus berlanjut sampai munculnya gerakan, yakni sebuah upaya mewujudnyatakan Ajeg Bali dalam berbagai kegiatan simbolis maupun aktual setelah peledakan bom di Legian tahun 2002, yang

${ }^{31}$ Ibid, h. 7

${ }^{32}$ Ibid, h. 10-11

${ }^{33}$ Lihat, Geoffrey Robinson, The Dark Side of Paradise Political Violence in Bali (Ithaca: Cornell University Press, 1998), h. 39.

${ }^{34} \mathrm{Ibid}, \mathrm{h} .12$ 
bahkan berlangsung sampai sekarang. Persaingan mereka bertujuan untuk menguasai kepemimpinan moral dan intelektual, bahkan politik dengan cara memanfaatkan dan mengelola wacana-wacana besar yang berkembang di masyarakat..$^{35}$ Tujuannya adalah untuk meneguhkan atau mengajegkan Bali yang diartikulasikan sebagai konsep kebudayaan, yang dimaknai sebagai adat, agama, dan selanjutnya kesenian, sesuai dengan kepentingan masing-masing. ${ }^{36}$

a. Disartikulasi Gerakan Ajeg Bali

Biarpun istilah gerakan Ajeg Bali sudah diterima masyarakat, namun ketika Bali diartikulasikan sebagai konsep kebudayaan yang dimaknai sebagai adat dan agama leluhur, lalu muncul kelompok intelektual organik lainnya melakukan disartikulasi. Mereka adalah satu kelompok yang tidak begitu bersemangat mengajegkan semua warisan adat dan agama leluhur sejak kekuasaan Majapahit di Bali. Dalam konteks sosial, mereka adalah orang-orang yang berasal dari beragam kelas, antara lain rohaniawan, elite pemerintahan, wartawan, dosen dan guru. Sementara dalam konteks kultural, mereka adalah kelompok yang ingin melakukan perubahan aspek adat dan agama kebudayaan Bali untuk disesuaikan dengan kemajuan zaman. Mereka membenci kebudayaan, terutama yang dibangun di atas prinsip sistem kasta, bahkan ingin menghancurkannya untuk digantikan dengan kebudayaan yang didasarkan pada ajaran Veda. Akan tetapi demi mencegah meluasnya kekuatan disintegratifperkembangan individualisme liberal dan tidak menjadi terasing di tengah-tengah lingkungan sosialnya, mereka akhirnya tetap sulit melepaskan diri dari ketergantungan terhadap kebudayaan masa lampau, peninggalan kekuasaan Majapahit, terutama dalam hal ritual. ${ }^{37}$

${ }^{35}$ Gerakan Ajeg Bali bisa disandingkan dengan "gerakan kemasyarakatan baru” yang diajarkan oleh Laclau dan Mouffe. Konsep yang meliputi berbagai gerakan atau perjuangan (struggle) yang tidak berbsasi kelas dan bukan gerakan buruh, antara lain gerakan kaum urban, gerakan lingkungan, gerakan anti-otoriterisme, gerakan anti-institusi, gerakan feminis, gerakan anti rasisme, gerakan etnis, gerakan regional, dan gerakan perddamaian Lihat Geogre Junus Aditjondro,"Teori Gerakan Kemasyarakatan Baru Laclau dan Mouffe,"download tanggal 12 Nopember 2009, melalui http;//www.geoogle.co.id., dalam Ibid,hlm 13

${ }^{36} \mathrm{Ibid}$.

${ }^{37}$ Ibid., h.128-129. 
Disartikulasi gerakan Ajeg Bali diwakili oleh kelompok jabawangsa. Akan tetapi tidak berarti semua orang jabawangsa menolak gerakan ajeg Bali dan sebaliknya semua orang triwangsa menyetujuinya. Orang-orang Jabawangsa yang merasakan dirinya terwakili dalam disartikulasi gerakan ajeg Bali umumnya berasal lima soroh (golongan) utama jabawangsa, yakni Bujangga, Pasek, Pande, Bendesa, dan Dukuh. Dalam konteks ideologis, mereka adalah orang Jabawangsa yang berpaham konservatif, yang ingin kembali ke situasi masa kejayaan leluhur mereka sebagai bangsawan Bali Kuno. Istilah ini tidak dapat diartikan sebagai bangsawan tinggi atau setingkat raja, sebab pada periode sejarah Bali Kuno yang berkuasa di Bali adalah raja-raja dari Jawa atau setidaknya identik dengannya. Mereka tidak dapat melupakan status leluhurnya sebagai orang yang pernah menduduki tempat terhormat, baik dalam pemerintahan maupun keagamaan. Mereka menganggap tingkat kebangsawanan kelompoknya lebih tinggi dari triwangsa. Mereka juga menganggap diri lebih asli Bali daripada golongan triwangsa. ${ }^{38}$

Selanjutnya, sebagian besar golongan triwangsa adalah agen pendukung dan penggerak Ajeg Bali, terutama ketika konsep itu diartikulasikan sebagai adat dan agama sejak Majapahit di Bali. Sebaliknya, golongan Jabawangsa yang pada awalnya mengartikulasikan Ajeg Bali sebagai adat dan agama pra Majapahit, namun akhirnya meluas menjadi agama Hindu. Salah satunya, dapat dilihat dari pendapat Ida Pandita Nabe Sri Bhagawan Dwija Warsa Nawa Sandhi. Ia berpendapat supaya manusia Bali berhati-hati memaknai Ajeg Bali. Harus ditegaskan sektor-sektor yang memang perlu diajegkan, supaya tidak mengajegkan feodalisme dan tradisi beragama gugon tuwon (seperti apa adanya dari sejak awal). Ia lebih setuju yang diajegkan agama Hindu di Bali, karena arahnya jelas, yaitu untuk membendung meluasnya pengaruh agama-agama lain. ${ }^{39}$

b. Mengelola Wacana Desa Adat dan Kasta

Pada saat Indonesia mengawali proses refomasi tahun 1998/1999. Semangat mengajegkan Bali diwujudnyatakan dengan cara

\footnotetext{
${ }^{38}$ Ibid., h. 129-130.

${ }^{39}$ Ibid, h. 131-132.
} 
mendisartikulasikan bangun desa adat peninggalan Orde Baru. Desa adat diposisikan sebagai warisan leluhur yang adiluhung, namun dianggap keropos karena digerogoti oleh berbagai kepentingan penguasa dan pengusaha, sehingga perlu dibenahi. ${ }^{40}$ Sementara itu, terhadap kasta, para intelektual organik dari berbagai golongan, bersikap mendua, di satu sisi mereka menyuarakan kesetaraan antara sesama manusia, namun di sisi lain memanfaatkan keuntungan darinya. Semangat refomasi tidak mendorong mereka untuk betulbetul menghapus sistem kasta, melainkan justru memperkuatnya melalui berbagai cara. ${ }^{41}$

Dalam persepsi masyarakat Bali secara umum, pengertian desa adat mencakup dua hal yaitu desa adatnya sendiri sebagai wadah dan adat istiadatnya sebagai isi dari pada wadahnya itu. Lebih lanjut dapat dijabarkan, bahwa desa adat merupakan suatu lembaga sosial tradisional yang mewadahi kegiatan sosial, budaya dan keagamaan masyarakat umat Hindu Bali. Adat istiadat adalah tatakrama kehidupan masyarakat umat Hindu Bali yang telah menjadi tradisi kemasyarakatan secara mantap sebagai warisan dari pada budaya bangsa. Desa adat tidak bisa dipisahkan dengan kehidupan sosial, budaya dan keagamaan masyarakat umat Hindu Bali, karena merupakan satu kesatuan yang bulat. ${ }^{42 "}$ Desa adat merupakan pelestari adat, budaya, serta menjadi lembaga Agama Hindu di Bali". "Desa adat dari semula adalah desa religious dan berstatus otonom yang awalnya disebut sima swatantra, Lembaga desa adat ini dibangun berdasarkan tatwa (ajaran Hindu)".

Dari kutipan-kutipan tersebut, dapat disimpulkan bahwa desa adat dipahami orang Bali sebagai lokus utama dari ekspresi sosial dan budaya orang Bali. Sistem sosial budaya itu sendiri mengacu kepada adat istiadat dan ajaran serta praktek agama Hindu. Jika kita telaah intensitas dan wujud interaksi sosial dan aneka ritual keagamaan di desa adat, bisa dipahami bahwa

${ }^{40}$ Lihat, Thomas Reuter,"Global trends in religion and reaffirmation of Hindu identity in Bali,' (Monahs: University Press, 2008), h. 11.

${ }^{41}$ Leo Howe, Hinduism \& Hierarchy in Bali (New Mexico: School of American Research Press, 2001), h. 3.

${ }^{42}$ Majelis Pembina Lembaga Adat Daerah Tingkat I (Bali: 1991), h. 45, dalam Thung Ju Lan, et. al., Klaim, Kontestasi \& Konflik Identitas: Lokalitas vis-à-vis Nasionalitas, (LIPI: 2005), h. 71. 
memang desa adat merupakan miniatur atau representatif dari hampir keseluruhan, atau paling tidak karakteristik utama dari wujud sosial budaya orang Bali. Dan karena sistem sosial dan budaya, agama termasuk di dalamnya, adalah acuan dari identitas kesukubangsaan, maka kita bisa mengatakan bahwa batasan desa adat adalah juga merupakan batasan dari etnik Bali. Dalam kontek demikian, tidaklah mengherankan jika orang Bali begitu terikat desa adatnya. Kecuali ingin mengingkari ke-Baliannya, setiap orang Bali akan berusaha untuk tidak melepaskan diri dari ikatan kesatuan desa adat. Jika dia berada jauh dari Bali, di luar negeri sekalipun, orang Bali selalu akan berusaha melanggengkan hubungannya dengan desa adat melalui berbagai cara. Dalam konteks ritual pun, orang Bali akan mencoba menghadirkan kekuatan-kekuatan supranatural yang mereka sembah di pura-pura desa adatnya ke tempat persembahyangan mereka di tempat masing-masing, terutama tempat persembahyangan di rumah. ${ }^{43}$

Dalam hal kasta, diakui bahwa pembicaran tentang riwayat kasta ini muncul, masih merupakan masalah sejarah yang paling ruwet dan membingungkan. Yangjelas sudah merupakan kenyataan pokok bahwa selama kurun dua ribu tahun sebelum Masehi, suatu golongan ras Arya yang memiliki bahasa, kebudayaan, dan ciri jasmani yang khas (tinggi, berkulit putih, bermata biru dan berambut lurus), datang ke benua India. Perbenturan perbedaan yang terjadi kemudian menimbulkan sistem kasta, jika kita tidak mau mengatakan bahwa hal itu secara langsung menciptakan sistem tersebut. Mungkin tidak sepenuhnya dapat kita ungkapkan secara pasti seberapa jauhkah peranan faktor-faktor berikut ini terhadap timbulnya pola kasta tersebut: yaitu faktor perbedaan etnis, warna kulit, adanya perkumpulan para tukang yang mempunyai rahasia keterampilan yang hendak dipeliharanya sendiri, aturan kesehatan yang membatasi hubungan antara golongan-golongan yang mempunyai daya tahan yang berbeda terhadap berbagai penyakit yang ada, dan larangan magis-keagamaan terhadap pencemaran dan kebersihan. Bagaimanapun juga, hasil yang timbul adalah suatu masyarakat yang secara tegas terbagi dalam empat golongan:

${ }^{43}$ Ibid., h. 72 . 
pemimpin rohani (brahmana), administrator (ksatria), tukang (waisya), dan para pengikut (sudra). ${ }^{44}$

\section{c. Disartikulasi Konsep Desa Adat}

Perwujudan nyata pemikiran untuk membenahi desa adat dilakukan dengan cara mendisartikulasikan Undang-Undang Republik Indonesia no. 5 tahun 1979 tentang Pemerintahan Desa, yang mengatur penyeragaman sistem pemerintahan desa di Indonesia. Berdasarkan Undang-Undang ini, maka struktur pemerintahan desa di Indonesia meliputi: desa, keluruhan, dusun, dan lingkungan.

Desa merupakan suatu wilayah yang ditempati oleh sejumlah penduduk sebagai kesatuan masyarakat termasuk di dalamnya kesatuan masyarakat hukum yang mempunyai organisasi pemerintahan terendah Langsung di bawah Camat dan berrhak menyelenggarakan rumah tangganya sendiri dalam Ikatan Kesatuan Republik Indonesia; Kelurahan adalah suatu wilayah ditempati oleh sejumlah penduduk yang mempunyai organisasi pemerintahan terendah langsung di bawah Camat, yang berhak menyelenggarakan rumah tangganya sendiri; Dusun adalah bagian wilayah dalam desa yang merupakan lingkungan kerja pelaksanaan pemerintahan desa; dan lingkungan adalah bagian wilayah dalam Kelurahan yang merupakan lingkungan kerja pelaksanaan pemerintahan Desa. ${ }^{45}$

\section{1) Proses Terjadinya Disartikulasi}

Disartikulasi terhadap artikulasi pemerintahan desa warisan pemerintahan Orde Baru ternyata tidak berjalan seperti yang diinginkan.AturanUndang-Undang No.5tahun1979yangdisesuaikan oleh pemerintah daerah Bali tahun 1983 tetap berlaku, karena tidak mungkin didisartikulasikan. Perhatian pun dialihkan hanya pada desa adat, yang tidak terjangkau oleh undang-undang ini. Keinginan untuk melakukan disartikulasi terhadap desa adat didasarkan pada suatu anggapan bahwa desa adat yang memiliki awig-awig (aturan

${ }^{44}$ Huston Smith, Agama-Agama Manusia, edisi ke-11, (Jakarta: Yayasan Obor Indonesia, 2001), h. 77-78.

${ }^{45}$ Lihat"Undang-undang Republik Indonesia Nomor 5 tahun 1979 tentang Pemerintahan Desa "dalam. I Nyoman Wijaya, Mencintai Diri..., h. 142-143 
adat) yang dipakai sebagai pedoman untuk menjaga keamanan dan ketertiban desa, seharusnya mampu menjalankan fungsinya sebagai benteng kebudayaan Bali. Akan tetapi dalam kenyataannya lembaga ini tidak memiliki kekuatan hukum terhadap para pendatang dari dalam maupun luar negeri yang tinggal di wilayahnya, sehingga tidak jarang di suatu wilayah desa adat terjadi berbagai masalah sosial seperti pemukiman liar, pekerja seks komersial (PSK), dan dekadensi moral lainnya. Desa adat juga tidak memiliki kekuatan untuk mencegah dan melawan keinginan para investor yang didukung oleh penguasa lokal dan nasional untuk membangun infrastruktur pariwisata yang lokasinya berdekatan dengan tempat-tempat suci, di antaranya adalah Bali Nirwana Resort (BNR) di dekat kawasan pura tanah lot, Tabanan. Proyek ini dibangun diatas tanah seluas 121 hektar oleh perusahaan Bakrie Brothers. Setiap petani menerima uang ganti rugi antara dua juta sampai lima juta. ${ }^{46}$ Saham BNR juga dimiliki oleh Bambang Triatmojo, salah seorang putra mantan presiden Suharto, melalui perusahannya, Permindo Oil Ttrading Company. Demikian pula pembangunan garuda wisnu kencana (gwk) yang dianggap melecehkan dewa wisnu sebagai salah satu simbol agama Hindu. ${ }^{47}$ Persoalan ini menimbulkan keberanian orang-orang bali, melakukan perlawanan dengan cara berunjuk rasa di tempattempat umum pada tahun 1994, yang mengakhiri ketakutan mereka kekuasaan orde baru yang represif dan otoriter. ${ }^{48}$

2) Artikulasi Baru Desa Adat

Langkah awal yang ditempuh untuk dapat memiliki sebuah desa adat yang ideal adalah mencabut peraturan daerah (Perda) Bali nomor 6 tahun 1986 dan menggantikannya dengan Peraturan Daerah (Perda) Provinsi Bali nomor 3 tahun 2001. ${ }^{49}$ Suatu hal yang menonjol dari perda ini adalah adanya pergantian nama dari desa adat menjadi desa pakraman. Ada dua pendapat yang berlawanan mengenai konsep desa pakraman. Seorang intelektual organik

${ }^{46}$ Henk Schulte Nordholt, Bali an Open Fortress 1995-2005;Regional Autonomy, Electoral Democracy and Entrenched Identities (Singapore: Nus Press, 2007), h. 9.

${ }^{47} \mathrm{Ibid}$.

${ }^{48} \mathrm{Ibid}$.

${ }^{49}$ Ibid., h. 149. 
berpendapat, parkman berasal dari bentukan kata pa-krama-n..$^{50}$ akan tetapi pendapat ini ditentang oleh seorang kolumnis asalusul bahasa, yang mengatakan pakraman adalah pengucapan yang keliru dari kata ka-rama-n. ${ }^{51}$ dalam perda nomor 3 tahun 2001 itu, desa pakraman diartikan sebagai kesatuan masyarakat hukum adat di provensi Bali yang menjadi satu kesatuan tradisi dan tatakrama pergaulan hidup masyarakat umat Hindu secara turun temurun dalam ikatan kayangan tiga atau kayangan desa yang mempunyai wilayah tertentu dan harta kekayaan sendiri serta berhak mengurus rumah tangganya sendiri. ${ }^{52}$

3) Hegemoni dan Ekslusivisme Gaya Baru

Dengan melihat definisi tugas desa pakraman yang telah disebutkan di atas, maka disebutkan bahwa desa adat diperlukan sebagai Negara kecil (desa) yang berkoalisi dengan Negara besar (pemerintah) untuk berama-sama mewujudkan cita-cita Negara Republik Indonesia menuju masyarakat adil dan beradab berdasarkan pancasila. Di dalamnya termasuk juga mengemban tugas Negara dalam menjaga keamanan dan ketertiban. Hal itu dilihat dari dimasukannya perangkat pacalang, ${ }^{53}$ yang diartikan sebagai satuan tugas keamanan tradisional masyarakat bali yang mempunyai wewenang untuk menjaga keamanan dan ketertiban wilayah, baik ditingkat banjar pakraman dan atau wilayah desa pakraman. ${ }^{54}$

Demikianlah, kehadiran Undang-undang RI No. 22 tahun 1999 tentang Otonomi Daerah dijadikan momentum oleh para intelektual organic dari berbagai golongan untuk mengajegkan Bali, dengan cara mengubah nama desa adat menjadi desa pkraman. Akan tetapi pengubahan nama ini tidak serta merta mengakibatkan terjadinya perubahan dalam kehidupan sosial, karena sistem yang berlaku didalamnya, yang menyerupai tata kehidupan di zaman kerajaan colonial dibiarkan masih berlaku. Pemanfaatan tranformasi rezim kekuasaan untuk sebuah perubahan structural seperti tersebut di atas, relative tidak ditemukan pada masa pemerintahan Presiden

\footnotetext{
${ }^{50}$ Ibid.

${ }^{51}$ Ibid.

${ }^{52} \mathrm{Ibid}$

${ }^{53}$ Ibid, h. 166

${ }^{54} \mathrm{Ibid}, \mathrm{hlm}, 167$
} 
Soeharto dan Zaman sebelumnya, karena pada dasarnya orangorang Bali menerima begitu saja artikulasi pemerintahan desa yang dibangun oleh pemerintah kolonial. ${ }^{55}$

Adat merupakan kebiasaan yang melakat pada sebuah etnis atau suku bangsa tertentu yang bisa menjadi identitas keetnisannya. Sedangkan budaya adalah segenap potensi yang dimiliki manusia dalam upaya menciptakan dan menghasilkan kebudayaan yang bisa dipakai manusia dalam upaya mempertahankan hidupnya di dunia ini. Adapun yang dimaksud agama lokal ataupun istilah lainnya agama asli, atau agama tradisional adalah sebuah bentuk kepercayaan yang lahir dari proses dialektik antara manusia dengan kebudayaan, dan lingkungan hidupnya.

\section{Penutup}

Bali sebagai salah satu suku bangsa berhak mengembangkan identitas kebaliannya disesuaikan dengan adat, dan tradisi nenek moyangnya yang susah payah membangunnya. Sebagai upaya penyelamatan atas adat dan tradisi leluhurnya, maka masyarakat Bali pun mencoba merumuskan sebuah gerakan yang kemudian dikenal dengan gerakan Ajeg Bali, yang tujuannya tiada lain melestarikan nilai-nilai leluhur nenek moyangnya.

Walaupun dalam perjalananannya Gerakan Ajeg Bali terjadi dua bentuk perwujudan dari yang berpaham terhadap artikulasi dan juga paham disartikulasi, namun tetap saja mereka menginginkan nilai-nilai adat tetap terpelihara dan terjaga secara utuh dari budaya asing ataupun budaya global.

Gerekan Ajeg Bali, dengan nama apapun istilah ini disebutkan, selalu merupakan latihan intelektual dalam menciptakan simbol-simbol baru kebudayaan secara terus menerus untuk mendefinisikan kembali identitas kebalian orang Bali demi kepentingan kekuasaan, walaupun munculnya terkadang terkait setiap terjadinya peristiwa besar maupun transformasi rezim politik ataupun jenis rezim lainnya yang dianggap menyudutkan dan menyerang identitas kebalian. []

${ }^{55}$ Ibid, hlm 175 


\section{Daftar Pustaka}

Aditjondro," Geogre Junus, Teori Gerakan Kemasyarakatan Baru Laclau dan Mouffe,"download tanggal 12 Nopember 2009, melalui http;//www.geoogle.co.id.

Agung, Anak Agung Gde Putra, Peralihan Sistem Birokrasi dari Tradisional ke Kolonial, Yogyakarta: Pustaka Pelajar, 2001.

Atkison, Jane Monning, "Agama dan Suku Wana di Sulawesi Tengah, dalam Michael R.Dove (Penyunting), Peranan Kebudayaan Tradisional Indonesia Dalam Modernisasi, Yayasan Obor Indonesia,thn 1985.

Bagus, I Gusti Ngurah,"Pertentangan Kasta dalam bentuk Baru pada Masyarakat Bali," Denpasar: Jurusan Antropologi, 1969.

,"Surya Kanta Modern Kawangsan Movement of The Jaba Caste in Bali," Masyarakat Indonesia, Vol.II.No.2 Jakarta: LIPI, 1975.

Dove, Michael R., (Penyunting), Peranan Kebudayaan Tradisional Indonesia Dalam Modernisasi, Jakarta: Yayasan Obor Indonesia, 1985.

Fabian, J., "Culture,Time and the object of Anthropology," dalam Time and The Work of Antrhropology, New York: Haewood, 1991. Gramsci, Antonio, Slection From The Prison Notebooks, edited and translated by Quintin Hoare and Geoffrey Nowell Smith, New York: International Publisher, 1971.

Garna, Judistira K., Ilmu-Ilmu Sosial Dasar-Konsep-Posisi, Pascasarjana Unpad Bandung, 2001

Hobart, Mark, "The end of the world news:television and a problem of articulation in Bali," International Journal of Cultural Studies, Volume 3, June, 1999,

Howe, Leo, Hinduism \& Hierarchy in Bali New Mexico: School of American Research Press, 2001.

Kahmad, Dadang, Kuliah Antropologi, Pascasarjana IAIN Sunan Gunung Dajti Bandung, 2002. 
Kuntjara, Esther, Penelitian Kebudayaan Sebuah Panduan Praktis, Graha Ilmu, 2006.

Lan, Thung Ju, et.al., Klaim, Kontestasi \& Konflik Identitas: Lokalitas vis- a -vis Nasionalitas, LIPI, 2005.

Majelis Pembina Lembaga Adat Daerah Tingkat I Bali, 1991:45, dalam Thung Ju Lan, et.al., Klaim, Kontestasi \& Konflik Identitas: Lokalitas vis-à-vis Nasionalitas, LIPI, 2005.

Nordholt, Henk Schulte, Bali an Open Fortress 1995-2005;Regional Autonomy, Electoral Democracy and Entrenched Identities Singapore: Nus Press, 2007. , Kriminalitas, Modernitas, dan Identitas dalam Sejarah Indonesia, Yogyakarta: Pustaka Pelajar, 2002.

Pritchard, E.E. Evans, Teori-teori tentang Agama Primitif, cet. ke-1, Yogyakarta: PLP2M, 1984.

Reuter, Thomas, "Global trends in religion and reaffirmation of Hindu identity in Bali," Monash University Press, 2008.

Robinson, Geoffrey, The Dark Side of Paradise Political Violence in Bali, Ithaca: Cornell University Press, 1998.

Roucek, Josep S.,\& Warren, Roland L., Pengantar Sosiologi, Jakarta: PT. Bina Aksara, 1984,

Simpen AB, I Wayan, Kamus Bahasa Bali, Denpasar: PT Mabhakti,1985.

Smith, Huston, Agama-Agama Manusia, Jakarta: Yayasan Obor Indonesia, edisi XI 2001.

Soekanto, Soerjono, Sosiologi Suatu Pengantar, Jakarta, Raja Grafindo Persada, 1990.

Undang-undang Republik Indonesia Nomor 5 tahun 1979 tentang Pemerintahan Desa”.

Vickers, Adrian,"Hinduism and Islam in Indonesia: Bali and The Pasisir World,"Indonesia, no 44 oktober, 1987.

Wijaya, I Nyoman, Mencintai Diri Sendiri: Gerakan Ajeg Bali dalam sejarah Kebudayaan Bali 1910-2007, UGM,Yogyakarta, 2009. 
Deni Miharja

halaman ini bukan sengaja dikosongkan 